Social Mobility." M. N. Rutkevich and F. R. Filippov, "Social Sources of Recruitment of the Intelligentsia." L. F. Liss, "The Social Conditioning of Occupational Choice." O. I. Shkaratan, "Social Ties and Social Mobility." Iu. V. Arutiunian, "Social Mobility in the Countryside." Commentary by S. M. Lipset, "Social Stratification Research and Soviet Scholarship." Selected Bibliography. Partial List of Contributors.

ISSLEDOVANIIA PO SOTSIAL'NO-POLITICHESKOI ISTORII ROSSII: SBORNIK STATEI PAMIATI BORISA ALEKSANDROVICHA ROMANOVA. Edited by N.E. Nosov et al. Akademiia nauk SSSR, Institut istorii SSSR, Leningradskoi otdelenie. Trudy, vyp. 12. Leningrad: "Nauka," 1971. 399 pp. 1.98 rubles.

Contents: Preface by N. E. Nosov. S. N. Valk, "Boris Aleksandrovich Romanov." D. S. Likhachev, "B. A. Romanov i ego 'gid' Daniil Zatochnik." V. V. Mavrodin, "O plemennykh kniazheniiakh vostochnykh slavian." A. A. Zimin, "Smerdy v zakonodatel'stve Vladimira Monomakha." L. V. Cherepnin, "K voprosu o 'Poslanii' Daniila Zatochnika." N. A. Kazakova, "Rannie russko-niderlandskie torgovye kontakty." Ia. S. Lur'e, " $\mathrm{K}$ istorii prisoedineniia Novgoroda v 1477-1479 gg." A. L. Shapiro, "O 'pozhilom' Sudebnikov 1497 i 1550 gg." Iu. G. Alekseev, "Piatnadtsatirublevyi maksimum po sluzhiloi kabale, sluzhba s zemli i feodal'naia renta." N. N. Maslennikova, "Pomeshchiki i krest'iane Porkhovskogo uezda Shelonskoi piatiny k 40-m godam XVI v." S. O. Shmidt, "Novoe o Tuchkovykh (Tuchkovy, Maksim Grek, Kurbskii)." A. I. Kopanev, "Novgorodskie tamozhennye tseloval'niki 70-80-kh godov XVI v." N. E. Nosov, "Russkii gorod i russkoe kupechestvo $\mathrm{v}$ XVI stoletii ( $\mathrm{K}$ postanovke voprosa)." V. I. Rutenburg, "U istokov politicheskikh sviazei Rossii i Italii." R. G. Skrynnikov, "Boris Godunov i tsarevich Dmitrii." V. M. Paneiakh, "Dobrovol'noe kholopstvo v zakonodatel'stve XVI-XVII vv. (1550-1649 gg.)." E. N. Kusheva, "O plene kak istochnike kholopstva vo vtoroi polovine XVII v." A. G. Man'kov, " $\mathrm{K}$ istorii reformy posadskogo upravleniia 1699 g." A. N. Tsamutali, "Sotsial'no-politicheskaia istoriia Kievskoi Rusi v osveshchenii M. D. Zatyrkevicha." N. P. Poletika, "Prussiia i Krymskaia voina." N. M. Druzhinin, "Glavnyi komitet ob ustroistve sel'skogo sostoianiia." Iu. B. Solov'ev, "Samoderzhavie i vopros o sluzhebnykh preimushchestvakh dvorianstva v kontse XIX v." B. V. Anan'ich and R. Sh. Ganelin, "R. A. Fadeev, S. Iu. Vitte i ideologicheskie iskaniia 'okhranitelei' v 1881-1883 gg." L. M. Ivanov, "K voprosu o strakhovanii rabochikh v Rossii." A. A. Fursenko, "Mozhno li schitat' kompaniiu Nobelia russkim kontsernom?" U. A. Shuster, "Peterburgskie rabochie i lodzinskii lokaut 1907 g." L. E. Shepelev, "Aktsionernoe zakonodatel'stvo Vremennogo pravitel'stva." Spisok trudov B. A. Romanova. Nauchnoe zasedanie, posviashchennoe pamiati doktora istoricheskikh nauk professora B. A. Romanova, 16 noiabria $1957 \mathrm{~g}$.

\title{
LETTERS
}

\section{TO THE EDITOR:}

In her article on A. M. Kollontai (Slavic Review, June 1973) Barbara Evans Clements refers on page 323 to Lenin's "famous interview" with Klara Zetkin as having taken place in 1919. The date was autumn 1920. On page 330 Professor Clements writes that "Trotsky's theory of permanent revolution . . . asserted that in an agrarian society like Russia's, with its weakly developed bourgeoisie, the proletariat and peasantry would have to lead the capitalist stage of development. 
The workers, having accomplished that [What happened to the peasants?], would move on to build socialism with the assistance of general European revolution." The author's source for this statement is Deutscher, The Prophet Armed (New York, 1954, pp. 148-50). A re-reading of those pages by me reveals that Professor Clements has just about turned what Deutscher wrote on its head. Deutscher concludes his discussion on the subject of Trotsky's permanent revolution as follows: "Trotsky ... argued that the working class would by its own political supremacy in the revolution be compelled to carry the Russian Revolution from the bourgeois to the Socialist phase, even before the Socialist upheaval had begun in the West."

Referring on page 331 to Lenin's State and Revolution, Professor Clements tells us that this is a "work scholars label unrepresentative of his political theory. Its anarchism may have been foreign to Lenin's world view. . . " I could not agree less. State and Revolution envisions the revolutionary state as constructed in the same authoritarian spirit upon which, fifteen years earlier, Lenin's Chto delat' had founded the theory of the autocratic revolutionary party. Lenin's noted pamphlet spells statism with a capital S, and the existing "proletarian dictatorships" in Russia, China, Cuba, Yugoslavia, Albania, North Viet Nam, and North Korea evince few signs of "withering away." The very expression "withering away" is, of course, a mistranslation into English of Lenin's Russian word "dies off" (the state, that is), which, in turn, merely translates what Engels had written in German. But the phrase "withering away" does, in fact, quite truly render Lenin's intention-one of his great contributions to Marxism-Leninism-that the revolutionary state, once achieved, should endure for an extremely long time. In State and Revolution Lenin writes: "Consequently, we have a right to speak solely of the inevitable withering away of the state [this is from an English translation] emphasizing the protracted nature of this process and its dependence upon the rapidity of development of the higher phase of communism; leaving quite open the question of lengths of time, or the concrete forms of withering away, since material for the solution of such questions is not available" (Lenin, Collected Works, New York, 1932, vol. 21, bk. 2, p. 225). In 1918, when defending his dictatorship against Kautsky's attacks, Lenin wrote: "This historical truth is that in every profound revolution, the prolonged, stubborn and desperate resistance of the exploiters, who for a number of years retain important practical advantages over the exploited, is the rule. . . . The transition from capitalism to communism takes an entire historical epoch. Until this epoch is over, the exploiters inevitably cherish the hope of restoration. . . . In these circumstances, in an epoch of desperately acute war, when history presents the question of whether age-old and thousandyear-old privileges are to be or not to be-at such a time to talk about majority and minority, about pure democracy, about dictatorship being unnecessary. . . . What infinite stupidity and abysmal philistinism are needed for this!" (Lenin, Collected Works, Moscow, 1965, vol. 28, pp. 252-54).

To Lenin, the dictatorship of the proletariat meant nothing less than the dictatorship of the bourgeoisie turned upside down. It had nothing whatever in common with anarchism, except in the sense of a vague hope targeted for some distant and completely unpredictable future.

Stanley W. Page

City College of the City University of New York 